The Journal of Animal \& Plant Sciences, 31(1): 2021, Page: 121-130

ISSN (print): 1018-7081; ISSN (online): 2309-8694

\title{
COMBINED EFFECT OF GROWTH HORMONES AND GYPSUM INDUCES SALINITY TOLERANCE IN WHEAT UNDER SALINE-SODIC SOIL
}

\author{
K. Ahmed ${ }^{*}, 1$, G. Qadir' ${ }^{1}$ M. Q. Nawaz', M. A. Riaz', M. F. Nawaz' and M. M. A. Ullah ${ }^{3}$ \\ ${ }^{1}$ Soil Salinity Research Institute Pindi Bathian. Punjab Pakistan; ${ }^{2}$ Nuclear Institute for Agriculture and Biology, \\ Faisalabad Pakistan; ${ }^{3}$ Department of Biosciences, University of Wah, Wah Cant Pakistan \\ Corresponding author's email: khalilahmeduaf@gmail.com
}

\begin{abstract}
In recent decades effective regulatory role of phytohormones in plants in response to salinity has received considerable attention. However, their role acting in combination with gypsum still remain elusive. That is why, this two-year study was conducted to assess the effects of foliar application of salicylic acid and L-tryptophan with and without gypsum on wheat crop in a moderately salt affected soil with $\mathrm{EC}_{\mathrm{e}}: 4.71 \mathrm{dS} \mathrm{m}^{-1}, \mathrm{pH}_{\mathrm{s}}: 9.18$ and SAR: 31.82 . Treatments detail is as under: - (A). Amendments 1: gypsum @ 50\% GR, 2: without gypsum, (B). Plant hormones $\mathrm{T}_{1}$ : control, $\mathrm{T}_{2}$ : SA @10 $10^{-5} \mathrm{M}$, $\mathrm{T}_{3}$ : L-TRP @ $10^{-5} \mathrm{M}, \mathrm{T}_{4}$ : SA + L-TRP (each @ $10^{-5} \mathrm{M}$ in 1:1). Results indicated that growth and yield parameters were higher in $\mathrm{T}_{4}$ (SA+L-TRP @ 10-5 M in 1:1 ratio) with gypsum application @ 50\% of GR. Individual application of either salicylic acid (SA) or L-tryptophan (L-TRP) improved the yield in comparison to control but the effect was more remarkable with their combined application. Post-harvest soil analysis clearly demonstrated that gypsum application improved the physical and chemical properties when compared to without application of gypsum. Results highlighted that salinity tolerance of wheat crop was increased in most of the studied parameters when these plant hormones were applied in combination, indicating a positive interaction between salicylic acid and L-tryptophan in salinized conditions.
\end{abstract}

Key words: Abiotic stress. growth enhancer, cereal, soil quality.

Abbreviations used: GR (gypsum requirement); $\mathrm{pH}_{\mathrm{s}}$ ( $\mathrm{pH}$ of soil saturated past); SA (salicylic acid); L-TRP (Ltryptophan); $\mathrm{BD}$ (bulk density); $\mathrm{EC}_{\mathrm{e}}$ (electrical conductivity of soil extract); $\mathrm{HC}$ (hydraulic conductivity); SAR (sodium adsorption ratio).

https://doi.org/10.36899/JAPS.2021.1.0200

Published online August 26, 2020

\section{INTRODUCTION}

Plants being sessile organism have to withstand many biotic and abiotic stress factors in their natural habitat. Salinity is an insidious hazard of arid to semi-arid regions which is characterized by low rainfall, high temperature and high evapotranspiration (Kumar et al., 2015). This saline environment is one kind of the most stressful habitats which disrupts plants morphophysiological processes like plant growth, development and reproduction (Vaishnav et al., 2015), less photosynthesis by decreasing green pigments (Sudhir and Murthy, 2004) and reduced activity of various enzymes (Munns et al., 2006). Hence, plants evolved unique protective mechanism mediated by phytohormones to minimize damage under stressful environment (Verma et al., 2016). Wheat is a main source of vegetable protein and is extensively cultivated all around the world due to its adaptation to a wide range of climates. Wheat, being glycophyte show low growth and development in saline conditions that negatively affected the physiological and metabolic processes of the plant and ultimately the final crop yield (Saqib et al., 2012). To assure food security for the growing population, it is necessary to mitigate the detrimental effects of salinity on stressed plants by employing different strategies (Szabolcs, 1994). Plant hormones are important anti stressor which activate the physiological and morphological plasticity of plants under stressful conditions (Wani et al., 2016). High level of salinity alters a plant's hormonal balance and decreased the concentration of endogenous phytohormones in the plant tissues (Miransari and Smith, 2014). The most efficient phytohormones in the adaptive adjustments of plants under stress conditions are Salicylic acid, Abscisic acid (ABA) and Ethylene (Xiong et al., 2002). Salicylic acid (SA) is one of the potential phytohormones which plays a pivotal role in plant growth and development, and modulate plant responses under unfavorable environmental situations (Herrera-Vasquez et al., 2015). Exogenous supply of Salicylic acid (SA) confer salinity stress tolerance by reprogramming gas exchange, nutrient uptake, stomatal regulation, membrane stability, enzymes activities, water relations and ionic imbalances in various plants (Miao et al., 2015). However, various researchers reported that defensive role of exogenous SA in plant response to salinity stress depends on species and developmental stage of plant, SA concentration, mode of application, duration of treatment 
and plant species (Khan et al., 2015). Seed priming with SA @ $0.25 \mathrm{mM}$ alleviate the growth stress of V. faba under low to high salinity conditions (Anaya et al., 2015). Merwad and Abdel-Fattah (2015) stated that foliar application of ascorbic acids and salicylic acid produced the maximum fresh and dry weight of sorghum in two investigated seasons. Hormones interact with each other in both antagonistic and synergistic ways to accomplish signaling to protect the plants from environmental stresses (Cosgrove et al., 2000). Salicylic acid interacts cooperatively with other plant hormones to mediate various aspects of plant responses to allow resource optimization under stress conditions (Horvath et al., 2015; Visentin et al., 2016). Interaction between SA and indole acetic acid has also been implicated in stress acclimation (Tamas et al., 2015). L-Tryptophan (L-TRY) is a major precursor of auxins and reported as more effective amino acid for plant growth and development than pure auxins (Zahir et al., 2000). It acts as an osmoprotectant, regulates the stomatal opening and ion transport (Rai, 2002). Exogenous application of LTryptophan@15 ppm and Salicylic Acid@100 ppm on maize regulates stomatal openings, improve relative water content, leaf membrane stabilization, potassium content and reduce transpirational water loss and carry on photosynthesis under drought (Rao et al., 2012). Furthermore, the detailed positive responses of phytohormones in combination with gypsum in salt stress remain unknown and additional data is required in this direction. Considering the role of SA to induce the salinity tolerance in crops and positive interaction among SA and L-Tryptophan, the effects of L-TRP and SA on wheat crop under salinity stress conditions were studied. So, a field study was carried out to investigate the response of wheat crop to exogenous application of SA and L-Tryptophan with and without gypsum in salt affected soil.

\section{MATERIALS AND METHODS}

This study was carried out for two consecutive winter seasons from 2014-15 to 2015-16 at Soil Salinity Research Institute Pindi Bhattian. For this purpose, saline sodic field $\left\{\mathrm{GR}=2.96 \mathrm{t}\right.$. $\mathrm{acre}^{-1}, \mathrm{EC}_{\mathrm{e}}=4.71 \mathrm{dS} \mathrm{m}^{-1}, \mathrm{pH}_{\mathrm{s}}=$ $9.18, \mathrm{SAR}=31.82$, hydraulic conductivity $=0.47 \mathrm{~cm} \mathrm{hr}^{-1}$ and bulk density $\left.=1.30 \mathrm{Mg} \mathrm{m}^{-3}\right\}$ was selected. The experimental design was split plot having four replications. Treatments comprised of; (A). Amendments: 1. Gypsum @ 50\% GR, 2. without gypsum and were applied in main plot. (B). Plant hormones: $\mathrm{T}_{1}$ : Control, $\mathrm{T}_{2}$ : SA @ $10^{-5} \mathrm{M}, \mathrm{T}_{3}$ : L-TRP @ $10^{-5} \mathrm{M}, \mathrm{T}_{4}$ : SA+ L-TRP (each @ $10^{-5} \mathrm{M}$ in 1:1) were executed in sub plots $(4 \times 6$ m). Gypsum @ 50\% GR was applied in their respective treatments followed by leaching one month before sowing of crop. Wheat cultivar (Faisalabad 2008) was sown in $2^{\text {nd }}$ week of November for two successive winter seasons. Uniform fertilizer @ 120-110-70 NPK kg ha-1 was applied to all treatments in the form of urea, single super phosphate and sulphate of potash respectively. Salicylic acid (SA) and L-TRP @ $10^{-5} \mathrm{M}$ solution were applied as foliar spray after 30 and 45 days of germination. For $\mathrm{Na}^{+}$and $\mathrm{K}^{+}$analysis, 10 plants were collected from each treatment at booting stage and the data regarding different agronomic parameters like plant height, number of tillers $/ \mathrm{m}^{2}$, spike length, No. of grains/spike, grains weight/spike, 1000-grains weight, grain and straw yield was recorded at maturity. Soil samples were collected for analysis of $\mathrm{pH}_{\mathrm{s}}, \mathrm{EC}_{\mathrm{e}}, \mathrm{SAR}$, $\mathrm{BD}$ and HC. All the soil and plant analysis were carried out following the method of U.S. Salinity Laboratory Staff (1969). Collected data were subjected to two-way factorial analysis of variance and least significance difference (LSD) test was used to sort out significant differences among the treatment means at $(P \leq 0.05)$ following the method of Steel et al. (1997) using STATISTIX 8.1 package software.

\section{RESULTS}

Plant height and Number of tillers: Data for the plant height showed that foliar application of hormones significantly $(P \leq 0.05)$ stimulated the plant growth in salt affected soil through an improvement in plant height for two consecutive seasons (Table-1). The magnitude of increased was more noticeable in SA than L-tryptophan treated plant. Furthermore, these findings revealed a link between SA and L-tryptophan and maximum plant height was observed when both hormones were applied in combination (Table-1). In main plots, significant impact on plant height was documented where gypsum was used (a) $50 \%$ GR as compared to plots receiving no gypsum.

Data regarding interactive effect of hormones and gypsum was also significant which showed that application of SA+ L-TRP each @1 $10^{-5} \mathrm{M}$ in 1:1 with gypsum significantly increased plant height; whereas minimum plant height was recorded in control treatment both in absence or presence of gypsum for two consecutive seasons. Number of tillers $\mathrm{m}^{-2}$ (Table-1) indicated that hormones, amendments and their interactive effect significantly increased tillers $\mathrm{m}^{-2}$. In main plots, maximum numbers of tillers were observed where gypsum was applied. While in subplots maximum number of tillers were noted where SA+ L-TRP each (a) $10^{-5} \mathrm{M}$ in 1:1 was used. Interaction between amendements and hormones was also found significant. Treatment receiving the combine application of $\mathrm{SA}+\mathrm{L}-$ TRP each @1 $10^{-5} \mathrm{M}$ in 1:1 with gypsum showed peak value of tillers, however at the same time individual application of SA or L-TRP also categorized the similar statistical trend. For both years, on average treatment mean basis increasing trend was divulged for plant height 
and numbers of tillers in $\mathrm{T}_{4}$ as compared to rest of the treatment means as shown in Table. 2.

Spike length and number of grains spike ${ }^{-1}$ : Data (Table 1) illustrated that gypsum did not produced a significant effect on spike length in $1^{\text {st }}$ season. However, in $2^{\text {nd }}$ season statistically a meaningful difference in spike length between gypsum treated and non-treated plots was observed. Similarly, hormones application has positive effect on spike length and higher spike length was noted where SA and L-TRP were applied in combination. Interaction between hormones and gypsum was also significant and maximum spike length was produced when two hormones were sprayed together each@10 $10^{-5} \mathrm{M}$ in $1: 1$ in the presence of gypsum. As far as grains spike ${ }^{-1}$ was concerned, data (Table 1) exhibited that grains spike${ }^{1}$ remained non-significant in first season with respect to amendments. However, in $2^{\text {nd }}$ season gypsum application produced significant number of grain spike ${ }^{-1}$ over the treatment where no gypsum was used. It was noted that grains spike ${ }^{-1}$ was significant in plants that received both hormones together in two consecutive seasons. Applying SA $@ 10^{-5} \mathrm{M}$ alone was also fall in the same statistical group. Interaction between gypsum and hormones showed that hormonal effeciency was more prononuced when two hormones were applied together with gypsum. Combine application of both harmones had markedly enhanced the spike length and grains per spike in both seasons to that of all other treatments means (Table 2).

Grain weight spike ${ }^{-1}$ and 1000-grain weight: Phytohormones and gypsum application had meaningful impact on grain weight spike ${ }^{-1}$ (Table 1). In total, grain weight spike $^{-1}$ progressively increased with gypsum application in both season than treatment where gypsum was not applied. Grain weight increase was also recorded when hormones were used alone or together. However, a synergistic effect was divulged for grain weight spike ${ }^{-1}$ which was statistically higher $(\mathrm{P} \leq 0.05)$ when both hormones were used together. Regarding the interaction of gypsum and hormones, data revealed that SA+ L-TRP (each @ $10^{-5} \mathrm{M}$ in 1:1) produced significantly higher grain weight per spike in gypsum treated plots. Data in Table 1 illustrated that gypsum treated plot produced statistically significant $(\mathrm{P} \leq 0.05) 1000$ - grain weight than plots without gypsum in both seasons. Exogenous hormonal application also had positive impact on this yield attribute. Spraying the plants with SA+ L-TRP increased 1000-grains weight. However, there was significant difference when both hormones were sprayed together in gypsum treated plots. Grain weight spike ${ }^{-1}$ and 1000-grain weight showed increasing trend in $\mathrm{T}_{4}$ to that of other treatment means in both years of study period (Table 2).

Grain yield and Straw yield: Data showed that gypsum and hormonal application significantly affected this yield characteristic (Fig 1). In main plots, gypsum treated plots recorded more grain yield than plots where gypsum was not applied and this positive effect on grain yield was more pronounced in second season. Plots subjected to spraying with SA or L-TRP also showed an enhancement in grain yield and this enhancement was significantly higher when both hormones were applied together than their individual use. Interaction between hormones and gypsum was also significant and maximum grain yield was produced when two hormones were sprayed together each @ $10^{-5} \mathrm{M}$ in 1:1 in presence of gypsum. A straw yield difference in response to amendment application was also observed in both seasons (data not shown). Gypsum application@ 50\% GR produced statistically significant $(\mathrm{P} \leq 0.05)$ straw yield than without gypsum. Plants treated with exogenous application of SA or LTRP also produced higher straw yield, and this difference was more pronounced when these hormones were sprayed together in gypsum treated plots.

$\mathrm{Na}^{+}$and $\mathbf{K}^{+}$concentration: Data showed that $\mathrm{Na}^{+}$ contents were higher in first crop than second crop. However, gypsum and hormonal application had decreased the $\mathrm{Na}^{+}$contents (Fig. 2). Gypsum application reduced the shoot $\mathrm{Na}^{+}$contents than without gypsum treated plots. Hormonal application also acted as antistress effect and minimum $\mathrm{Na}^{+}$contents were recorded were $\mathrm{SA}+\mathrm{L}-\mathrm{TRP}$ were applied together with gypsum. On contrary, potassium concentration increased with gypsum application and foliar spray of hormones in both seasons (Fig. 3). Maximum $\mathrm{K}^{+}$contents were recorded with application of gypsum and SA+ L-TRP each at @ $10^{-5} \mathrm{M}$ $1: 1$.

Soil properties: Analysis of composite soil samples at the end of study revealed that gypsum application significantly improved the soil chemical and physical properties and effective was more pronounced with application of phytohormones (Table 3). Salinity indices $\left(\mathrm{pH}_{\mathrm{s}}, \mathrm{EC}_{\mathrm{e}}\right.$ and $\mathrm{SAR}$ values) were significantly improved with application of gypsum. Maximum reduction of 5.01 $\%$ in $\mathrm{pH}_{\mathrm{s}}$ with respect to its initial value (at the start of study) was observed with gypsum application @ 50\% GR and plant were subjected to foliar spray of SA+ L-TRP (each@10-5 M in 1:1). Similarly, gypsum @ 50\% GR substantially lowered the $\mathrm{EC}_{\mathrm{e}}$ and $\mathrm{SAR}$ by $23.56 \%$ and $37.14 \%$ respectively when both hormones were sprayed together. The effect of soil chemical properties like $\mathrm{EC}_{\mathrm{e}}$, $\mathrm{SAR}$ and $\mathrm{pH}_{\mathrm{s}}$ was directly translated into soil physical properties. The greater value of BD showed harder and less porous soil. In this study, a significant decrease in this soil property occurred in two years with application of gypsum. A decrease of $5.38 \%$ in bulk density was noted with gypsum @ 50\% GR and phytohormones 
Table 1. Effect of growth hormones on plant growth traits of wheat in added and without gypsum plots.

\begin{tabular}{|c|c|c|c|c|c|c|c|c|c|c|c|c|}
\hline \multirow[t]{2}{*}{ Treatments } & \multicolumn{2}{|c|}{$\begin{array}{c}\text { Plant height } \\
\text { cm }^{\text {plant }}{ }^{-1}\end{array}$} & \multicolumn{2}{|c|}{$\begin{array}{c}\text { Number of tillers } \\
\mathbf{m}^{-2}\end{array}$} & \multicolumn{2}{|c|}{$\begin{array}{c}\text { Spike length } \\
(\mathrm{cm})\end{array}$} & \multicolumn{2}{|c|}{$\begin{array}{c}\begin{array}{c}\text { No. of grains } \\
\text { spike }^{-1}\end{array} \\
\end{array}$} & \multicolumn{2}{|c|}{$\begin{array}{c}\text { Grain weight spike }{ }^{-1} \\
\text { (g) }\end{array}$} & \multicolumn{2}{|c|}{$\begin{array}{c}1000 \text { Grain } \\
\text { weight }(\mathrm{g})\end{array}$} \\
\hline & $\begin{array}{c}\mathbf{5 0 \%} \\
\text { GR } \\
\end{array}$ & $\begin{array}{c}\mathbf{W} / \mathbf{O} \\
\text { gypsum }\end{array}$ & $\begin{array}{l}\mathbf{5 0 \%} \\
\text { GR }\end{array}$ & $\begin{array}{c}\mathrm{W} / \mathrm{O} \\
\text { gypsum }\end{array}$ & $\begin{array}{c}\mathbf{5 0} \% \\
\text { GR } \\
\end{array}$ & $\begin{array}{c}\text { W/O } \\
\text { gypsum }\end{array}$ & $\begin{array}{l}50 \% \\
\text { GR } \\
\end{array}$ & $\begin{array}{c}\mathbf{W} / O \\
\text { gypsum }\end{array}$ & $\begin{array}{c}\mathbf{5 0 \%} \\
\text { GR } \\
\end{array}$ & $\begin{array}{c}\text { W/O } \\
\text { gypsum }\end{array}$ & $\begin{array}{c}\mathbf{5 0 \%} \\
\text { GR } \\
\end{array}$ & $\begin{array}{c}\mathrm{W} / \mathrm{O} \\
\text { gypsum }\end{array}$ \\
\hline \multicolumn{13}{|c|}{ Year 2014-15 } \\
\hline $\mathrm{T}_{1}$ : Control & $65.2^{\mathrm{BC}}$ & $59.7^{\mathrm{D}}$ & $129.7^{\mathrm{D}}$ & $115.7^{\mathrm{E}}$ & $8.53^{\mathrm{CD}}$ & $7.76^{\mathrm{D}}$ & $21.7^{\mathrm{D}}$ & $22.3^{\mathrm{D}}$ & $0.92^{\text {B_D }}$ & $0.76^{\mathrm{E}}$ & $25.2^{\mathrm{C}}$ & $23.5^{\mathrm{D}}$ \\
\hline $\mathrm{T}_{2}: \mathrm{SA} @ 10^{-5} \mathrm{M}$ & $69.6^{\mathrm{AB}}$ & $63^{\mathrm{CD}}$ & $150.7^{\mathrm{AB}}$ & $132.3^{\mathrm{CD}}$ & $9.93^{\mathrm{AB}}$ & $8.40^{\mathrm{CD}}$ & $26.7^{\mathrm{A}}$ & $25.0^{\mathrm{A} \_\mathrm{C}}$ & $0.97^{\mathrm{B}}$ & $0.82^{\mathrm{CD}}$ & $28.5^{\mathrm{B}}$ & $25.2^{\mathrm{C}}$ \\
\hline T3: L-TRP@10-5 M & $66.3^{\mathrm{BC}}$ & $60.5^{\mathrm{D}}$ & $148.6^{\mathrm{B}}$ & $129.0^{\mathrm{D}}$ & $9.07 \mathrm{BD}$ & $8.26^{\mathrm{D}}$ & $23.3^{\text {B_D }}$ & $23.0^{\mathrm{CD}}$ & $0.94^{\mathrm{BC}}$ & $0.80^{\mathrm{DE}}$ & $28.0^{\mathrm{B}}$ & $24.7^{\mathrm{C}}$ \\
\hline $\mathrm{T}_{4}: \mathrm{SA}+\mathrm{L}-\mathrm{TRP}\left(\mathrm{each} @ 10^{-5} \mathrm{M}\right.$ in $\left.1: 1\right)$ & $71.3^{\mathrm{A}}$ & $63.6^{\mathrm{CD}}$ & $154.0^{\mathrm{A}}$ & $136.3^{\mathrm{C}}$ & $10.7^{\mathrm{A}}$ & $9.23^{\mathrm{A}-\mathrm{C}}$ & $27.6^{\mathrm{A}}$ & $25.3^{\mathrm{AB}}$ & $1.02^{\mathrm{A}}$ & $0.85^{\mathrm{B}}{ }_{-} \mathrm{D}$ & $29.6^{\mathrm{A}}$ & $25.5^{\mathrm{C}}$ \\
\hline Mean & $68.1^{\mathrm{A}}$ & $61.7^{\mathrm{B}}$ & $145.8^{\mathrm{A}}$ & $128.3^{\mathrm{B}}$ & $9.55^{\mathrm{A}}$ & $8.41^{\mathrm{A}}$ & $24.8^{\mathrm{A}}$ & $23.9^{\mathrm{A}}$ & $0.96^{\mathrm{A}}$ & $0.81^{\mathrm{B}}$ & $27.8^{\mathrm{A}}$ & $24.7^{\mathrm{B}}$ \\
\hline \multicolumn{13}{|c|}{ Year2015-16 } \\
\hline $\mathrm{T}_{1}:$ Control & $67.2^{\mathrm{BC}}$ & $58.9^{\mathrm{D}}$ & $142.7^{\mathrm{B}}$ & $124.7^{\mathrm{C}}$ & $8.23^{\mathrm{D}}$ & $7.63^{\mathrm{E}}$ & $24.3^{\text {C_E }}$ & $23.3^{\mathrm{E}}$ & $1.52^{\mathrm{B}}$ & $1.06^{\mathrm{D}}$ & $30.0^{\mathrm{B}}$ & $26.5^{\mathrm{C}}$ \\
\hline $\mathrm{T}_{2}: \mathrm{SA} @ 10^{-5} \mathrm{M}$ & $71.6^{\mathrm{AB}}$ & $61.3^{\mathrm{D}}$ & $165.0^{\mathrm{A}}$ & $141.3^{\mathrm{B}}$ & $9.80^{\mathrm{B}}$ & $9.30^{\mathrm{C}}$ & $29.7^{\mathrm{A}}$ & $26.7^{\mathrm{BC}}$ & $1.57^{\mathrm{B}}$ & $1.12^{\mathrm{CD}}$ & $33.5^{\mathrm{A}}$ & $28.2^{\mathrm{BC}}$ \\
\hline $\mathrm{T}_{3}: \mathrm{L}-\mathrm{TRP} @ 10^{-5} \mathrm{M}$ & $68.3^{\mathrm{AB}}$ & $59.8^{\mathrm{D}}$ & $161.3^{\mathrm{A}}$ & $138.0^{\mathrm{B}}$ & $9.06^{\mathrm{C}}$ & $8.23^{\mathrm{D}}$ & $26.3^{\text {B_D }}$ & $24.0^{\mathrm{DE}}$ & $1.55^{\mathrm{B}}$ & $1.14^{\mathrm{C}}$ & $33.0^{\mathrm{A}}$ & $27.7^{\mathrm{BC}}$ \\
\hline $\mathrm{T}_{4}: \mathrm{SA}+\mathrm{L}-\mathrm{TRP}\left(\mathrm{each} @ 10^{-5} \mathrm{M}\right.$ in $\left.1: 1\right)$ & $73.3^{\mathrm{A}}$ & $62.3^{\mathrm{CD}}$ & $165.7 \mathrm{~A}$ & $145.3^{\mathrm{B}}$ & $10.8^{\mathrm{A}}$ & $9.20^{\mathrm{C}}$ & $30.0^{\mathrm{A}}$ & $27.7^{\mathrm{AB}}$ & $1.64^{\mathrm{A}}$ & $1.15^{\mathrm{C}}$ & $34.8^{\mathrm{A}}$ & $29.5^{\mathrm{B}}$ \\
\hline Mean & $70.1^{\mathrm{A}}$ & $60.6^{\mathrm{B}}$ & $158.6^{\mathrm{A}}$ & $137.3^{\mathrm{B}}$ & $9.5^{\mathrm{A}}$ & $8.6^{\mathrm{B}}$ & $27.6^{\mathrm{A}}$ & $25.4^{\mathrm{B}}$ & $1.57^{\mathrm{A}}$ & $1.12^{\mathrm{B}}$ & $32.8^{\mathrm{A}}$ & $28.0^{\mathrm{B}}$ \\
\hline
\end{tabular}

Different letters in the same column indicate significant differences by LSD at $\mathrm{P} \leq 0.05$.

Table 2. Effect of growth hormones on treatment means of plant growth traits of wheat in added and without gypsum plots.

\begin{tabular}{|c|c|c|c|c|c|c|}
\hline Treatments & $\begin{array}{c}\text { Plant height } \\
\text { cm plant }^{-1}\end{array}$ & $\begin{array}{c}\text { Number of } \\
\text { tillers } \mathbf{~ m}^{-2}\end{array}$ & $\begin{array}{c}\text { Spike length } \\
(\mathrm{cm})\end{array}$ & $\begin{array}{c}\text { No. of grains } \\
\text { spike }^{-1} \\
\end{array}$ & $\begin{array}{l}\text { Grain weight } \\
\text { spike }^{-1}(\mathrm{~g})\end{array}$ & $\begin{array}{l}1000 \text { Grain } \\
\text { weight (g) }\end{array}$ \\
\hline \multicolumn{7}{|c|}{ Year 2014-15 } \\
\hline $\mathrm{T}_{1}:$ Control & $62.4 \mathrm{C}$ & $122.7 \quad \mathrm{C}$ & 8.15 & $22.00 \mathrm{~B}$ & 0.84 & $24.33 \mathrm{C}$ \\
\hline $\mathrm{T}_{2}: \mathrm{SA} @ 10^{-5} \mathrm{M}$ & $66.2 \mathrm{AB}$ & $141.5 \mathrm{AB}$ & $9.16 \mathrm{~B}$ & $25.83 \mathrm{~A}$ & $0.89 \mathrm{~B}$ & $26.83 \mathrm{AB}$ \\
\hline $\mathrm{T}_{3}: \mathrm{L}-\mathrm{TRP} @ 10^{-5} \mathrm{M}$ & $63.4 \mathrm{BC}$ & $138.8 \mathrm{~B}$ & $8.66 \mathrm{BC}$ & $23.16 \mathrm{~B}$ & $0.87 \mathrm{BC}$ & $26.33 \mathrm{~B}$ \\
\hline $\mathrm{T}_{4}: \mathrm{SA}+\mathrm{L}-\mathrm{TRP}\left(\mathrm{each} @ 10^{-5} \mathrm{M}\right.$ in $1: 1$ ) & $67.5 \mathrm{~A}$ & $145.2 \mathrm{~A}$ & $9.95 \mathrm{~A}$ & $26.50 \mathrm{~A}$ & $0.94 \mathrm{~A}$ & $27.58 \mathrm{~A}$ \\
\hline \multicolumn{7}{|c|}{ Year $2015-16$} \\
\hline $\mathrm{T}_{1}:$ Control & $63.1 \mathrm{~B}$ & $133.7 \mathrm{C}$ & $7.93 \quad \mathrm{D}$ & $23.83 \mathrm{~B}$ & 1.29 & $28.25 \mathrm{C}$ \\
\hline $\mathrm{T}_{2}: \mathrm{SA} @ 10^{-5} \mathrm{M}$ & $66.5 \mathrm{AB}$ & $153.2 \mathrm{AB}$ & $9.55 \mathrm{~B}$ & $28.16 \mathrm{~A}$ & $1.34 \mathrm{~B}$ & $30.83 \mathrm{AB}$ \\
\hline $\mathrm{T}_{3}: \mathrm{L}-\mathrm{TRP} @ 10^{-5} \mathrm{M}$ & $64.1 \mathrm{~B}$ & 149.7 B & $8.65 \mathrm{C}$ & $25.16 \mathrm{~B}$ & $1.35 \mathrm{~B}$ & $30.33 \mathrm{~B}$ \\
\hline $\mathrm{T}_{4}: \mathrm{SA}+\mathrm{L}-\mathrm{TRP}\left(\mathrm{each} @ 10^{-5} \mathrm{M}\right.$ in $\left.1: 1\right)$ & $67.8 \mathrm{~A}$ & $155.5 \mathrm{~A}$ & $9.98 \mathrm{~A}$ & $28.83 \mathrm{~A}$ & $1.40 \mathrm{~A}$ & $32.16 \mathrm{~A}$ \\
\hline
\end{tabular}

Different letters in the same column indicate significant differences by LSD at $\mathrm{P} \leq 0.05$ 
(each $@ 10^{-5} \mathrm{M}$ in 1:1) Fig 4. Hydraulic conductivity, also increased manifold during two years with a maximum of $0.56 \mathrm{~cm} \mathrm{hr}^{-1}(19.14 \%$ increase $)$ when gypsum @ 50 \% GR and SA+ L-TRP were applied together Fig 5.

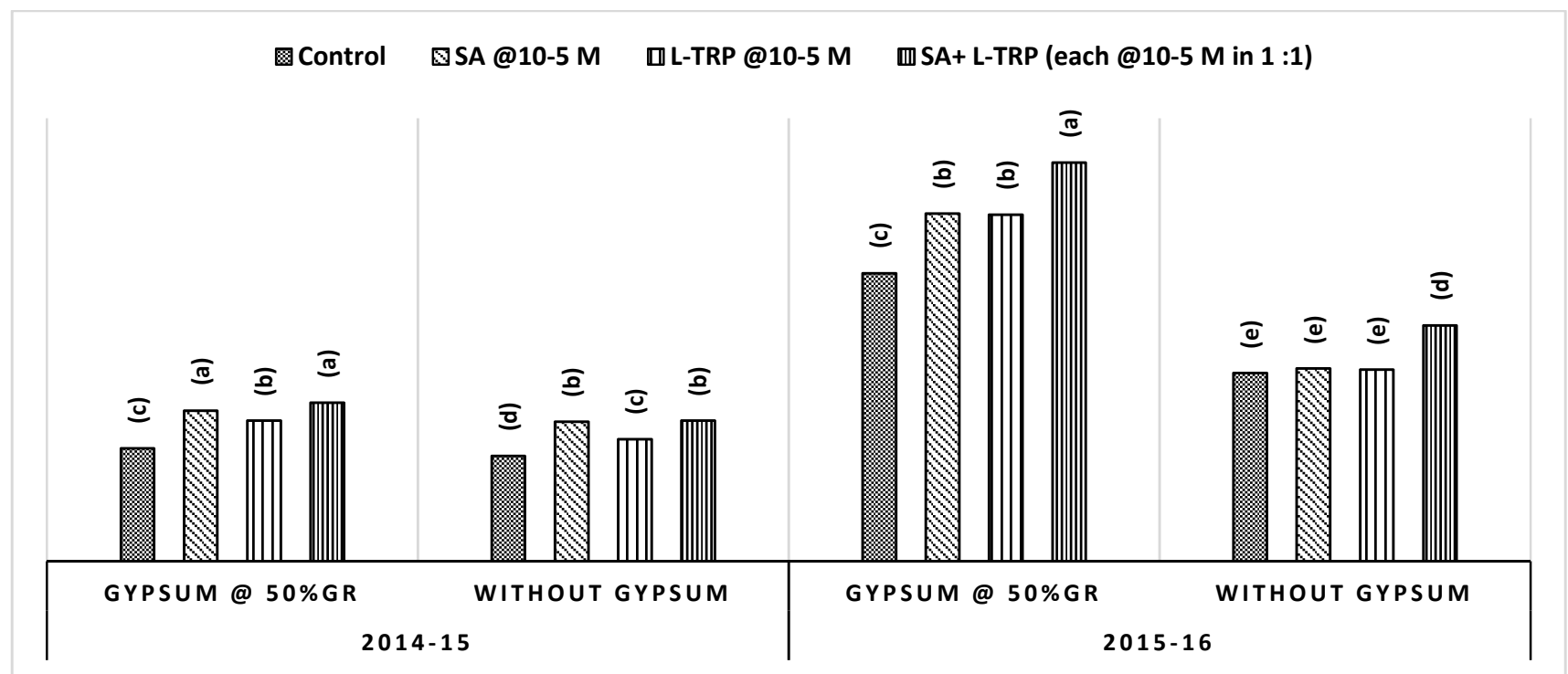

Fig 1. Effect of growth hormones on wheat grain yield (t. ha $\left.{ }^{-1}\right)$ in added and without gypsum addition

Table-3. Soil analyses at the end of study.

\begin{tabular}{|c|c|c|c|c|c|c|}
\hline \multirow[t]{2}{*}{ Treatments } & \multicolumn{2}{|l|}{$\mathrm{pH}_{\mathrm{s}}$} & \multicolumn{2}{|c|}{$E C_{\mathrm{e}}\left(\mathrm{dS} \mathrm{m}^{-1}\right)$} & \multicolumn{2}{|c|}{ SAR } \\
\hline & $\begin{array}{l}\text { Gypsum } \\
(50 \% \text { GR) }\end{array}$ & $\begin{array}{l}\text { Without } \\
\text { gypsum }\end{array}$ & $\begin{array}{l}\text { Gypsum } \\
(50 \% \text { GR) }\end{array}$ & $\begin{array}{l}\text { Without } \\
\text { gypsum }\end{array}$ & $\begin{array}{l}\text { Gypsum } \\
\text { (50\%GR) }\end{array}$ & $\begin{array}{l}\text { Without } \\
\text { gypsum }\end{array}$ \\
\hline $\mathrm{T}_{1}$ : Control & 8.79 & 8.86 & 3.88 & 4.30 & 23.70 & 27.80 \\
\hline $\mathrm{T}_{2}: \mathrm{SA} @ 10^{-5} \mathrm{M}$ & 8.75 & 8.81 & 3.76 & 3.95 & 21.75 & 26.10 \\
\hline T3:L-TRP @10-5 M & 8.78 & 8.84 & 3.80 & 3.97 & 22.90 & 26.70 \\
\hline $\begin{array}{l}\mathrm{T}_{4}: \mathrm{SA}+\mathrm{L}-\mathrm{TRP} \\
\left(\text { each } @ 10^{-5} \mathrm{M} \text { in } 1: 1\right)\end{array}$ & 8.72 & 8.80 & 3.60 & 3.90 & 20.00 & 25.00 \\
\hline
\end{tabular}

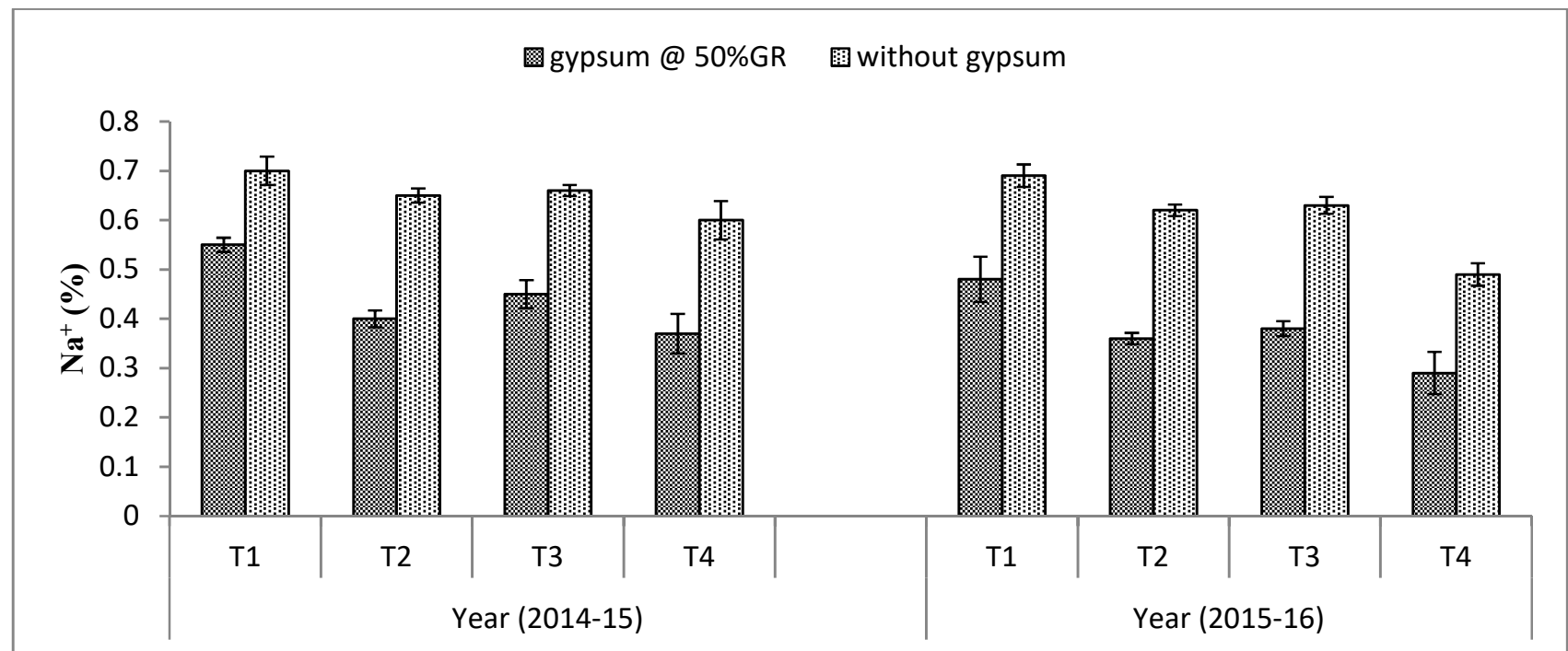

Fig. 2. Interactive effect of hormones and gypsum on $\mathrm{Na}^{+}(\%)$ contents of wheat shoot. $\mathrm{T}_{1}$ (control), $\mathrm{T}_{2}\left(\mathrm{SA} @ 10^{-5}\right.$ M), T3 (L-TRP@10-5 M), T 4 (SA + L-TRP (each @ $10^{-5} \mathrm{M}$ in 1:1). 


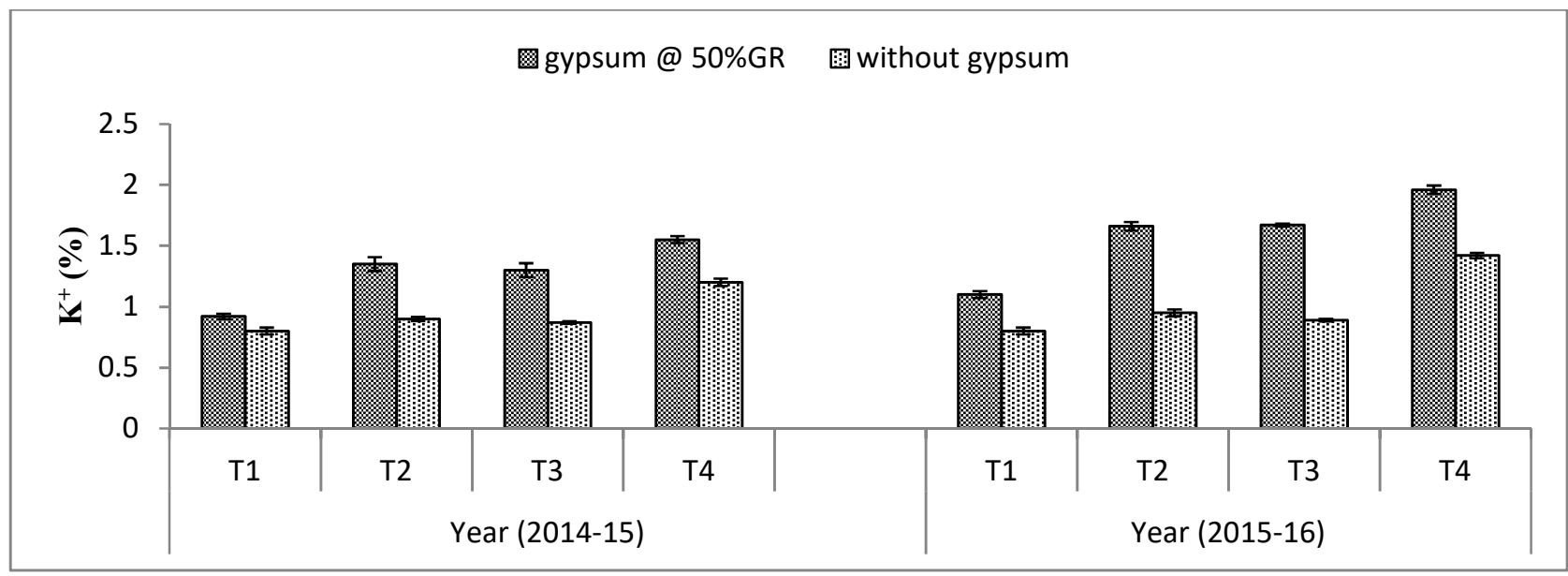

Fig. 3. Interactive effect of hormones and gypsum on $\mathrm{K}^{+}(\%)$ contents of wheat shoot. $\mathrm{T}_{1}$ (control), $\mathrm{T}_{2}\left(\mathrm{SA} @ 10^{-5}\right.$ M), T3 $\left(\right.$ L-TRP@10 $\left.0^{-5} \mathrm{M}\right), \mathrm{T}_{4}\left(\mathrm{SA}+\mathrm{L}-\mathrm{TRP}\left(\operatorname{each} @ 10^{-5} \mathrm{M}\right.\right.$ in 1:1).

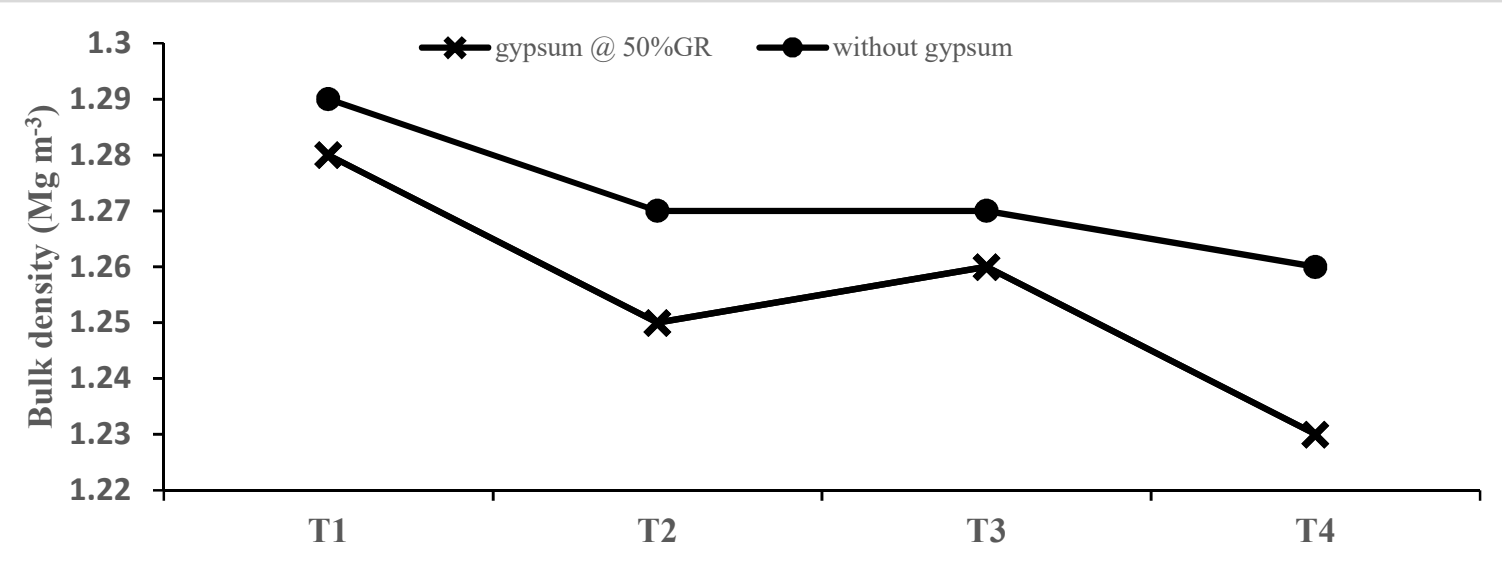

Fig. 4. Interactive effect of hormones and gypsum on bulk density $\left(\mathrm{Mg} \mathrm{m}^{-3}\right)$ of soil at the end of study. $\mathrm{T}_{1}$ (control), $T_{2}\left(S A @ 10^{-5} M\right), T_{3}\left(L-T R P @ 10^{-5} M\right), T_{4}\left(S A+L-T R P\left(e a c h @ 10^{-5} M\right.\right.$ in 1:1).

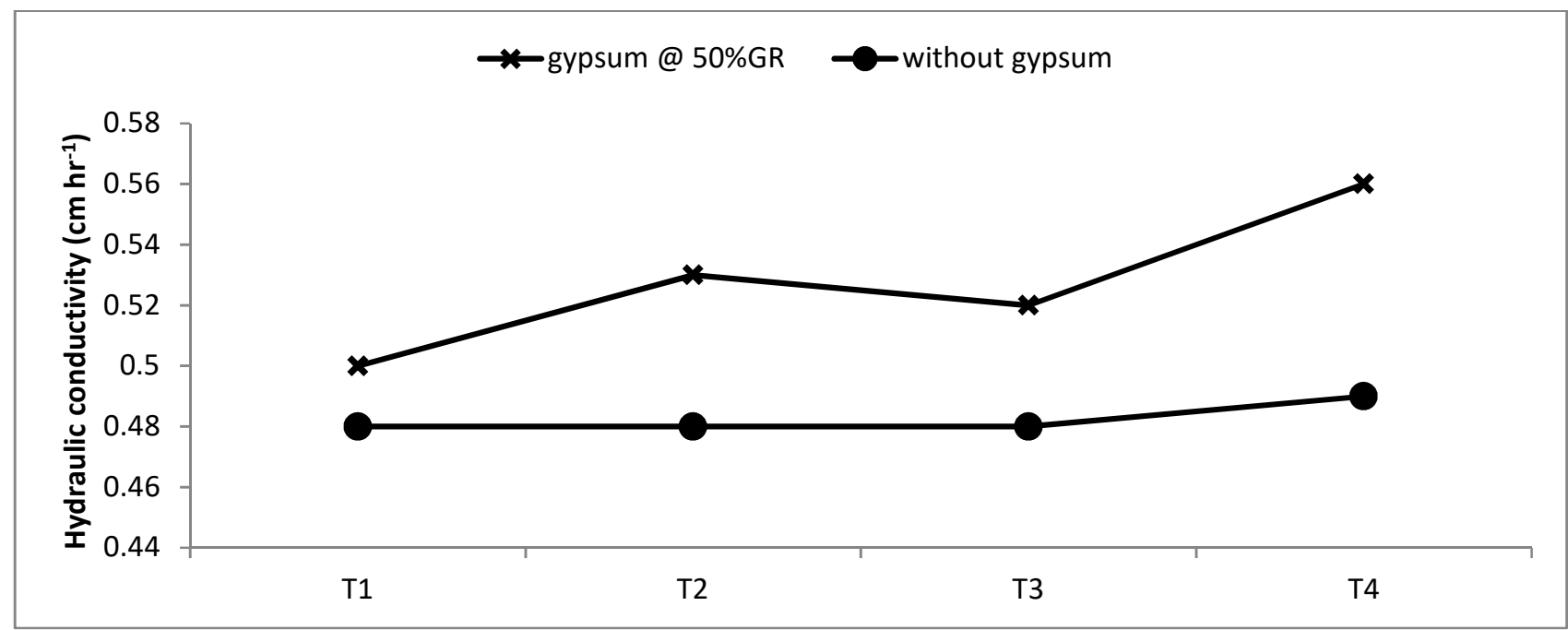

Fig. 5. Interactive effect of hormones and gypsum on hydraulic conductivity $\left(\mathrm{cm} \mathrm{hr}^{-3}\right)$ of soil at the end of study. $T_{1}$ (control), $T_{2}\left(\mathrm{SA} @ 10^{-5} \mathrm{M}\right), \mathrm{T}_{3}\left(\mathrm{~L}-\mathrm{TRP} @ 10^{-5} \mathrm{M}\right), \mathrm{T}_{4}\left(\mathrm{SA}+\mathrm{L}-\mathrm{TRP}\left(\operatorname{each} @ 10^{-5} \mathrm{M}\right.\right.$ in 1:1) 


\section{DISCUSSION}

Accumulation of salts in growth medium lowered the solute potential and affect negatively the plant metabolism leading to decreased plant growth, development and productivity. In current study, overall decrease in growth parameters e.g., plant height and No. of tillers in treatments without growth regulator and gypsum may be due to ion toxicity, decreased photosynthesis, disturbance in osmoprotectants, stomatal closure and the increased production of reactive oxygen species (Daneshmand et al., 2010). Reduction in growth under salinized environment was also described by Amjed et al. (2014) in wheat and Riaz et al. $(2008,2012)$ in sunflower. Application of phytohormones dampened the adverse effects of salinity and a significant increase in above mentioned characteristics in response to hormones either alone or in combination each of SA or tryptophan was noted. However, at the same time SA has more positive effect than corresponding level of tryptophan. Interaction between SA and tryptophan was synergistic and produced a stimulatory effect on growth of wheat seedling and addition of gypsum further increased the value of these attributes. It is well established fact that SA has potential to affect plant growth and stress response against salinity by improving ion uptake, water relations, photosynthesis, membrane stabilization, and stomatal regulations (Said-Al Ahl et al., 2014). In this study, SA along with tryptophan enhanced the growth and yield related attributes of wheat which are in accordance with the findings of Hala (2005) who reported substantial increase in growth and grain yield of wheat with application of nicotinamide or tryptophan. Similarly, addition of SA@100 mg L $\mathrm{m}^{-1}$ overcome the reduction in biomass, improve the chlorophyll contents and gas exchange attributes and protect the plant under salinized environment (Babar et al., 2014). The observed increase in growth and yield characteristics may also be concomitant to IAA induced water relation, availability of nutrients and development of better root system (Mohite, 2013). Wheat crop also gained the advantages of the ameliorating effects of gypsum on soil chemical and physical properties (Ahmed et al., 2015). So it is inferred from the results that application of SA and tryptophan improved the growth characteristic by stimulating ion uptake e.g., $\mathrm{N}, \mathrm{P}, \mathrm{Ca}^{2+}$ and $\mathrm{Mg}^{2+}$ (Desoky and Merwad 2015), improved $\mathrm{K}^{+} / \mathrm{Na}^{+}$(Tufail et al., 2013), membrane stabilization (Hussain et al., 2014) nevertheless, combination of SA and tryptophan had more beneficial effect than their individual use which suggest these hormones act cooperatively. Hala (2005) also reported that addition of nicotinamide or tryptophan decreased $\mathrm{Na}^{+}$and $\mathrm{Cl}^{-}$content and increased $\mathrm{K}^{+}$and $\mathrm{Ca}^{2+}$ in the wheat shoots. These results are in line with previously published report on fenugreek (Babar et al., 2014), wheat (Iqbal and Ashraf, 2013) and barley (El-Tayeb, 2005) that foliar applied salicylic acid and tryptophan enhanced vegetative growth. Exposure of wheat seedling to SA or tryptophan caused a remarkable increase in yield and yield attributes compared to plants that were not treated with SA or L-tryptophan. However, data obtained revealed that combined treatment of SA + L-tryptophan with gypsum displayed a significant effect on aforementioned attribute than their individual use. Under optimum growth conditions, the balance between ROS production and elimination is precisely regulated by plant antioxidant defense system (Hameed et al., 2011). While salinity stress disturbed the photosynthetic activity and other various biochemical processes controlling plant growth and crop productivity (Tiwari et al., 2010) leading to increased generation of reactive oxygen species (Asada, 2006). Majority of studies suggest that phytohormones play a pivotal role in eliminating reactive oxygen species (ROS) and maintained equilibrium between the production and detoxification of ROS (Mittler, 2002). This enhanced antioxidant system dampened detrimental effects of salinity and protects the plants (Kang et al., 2013). Increased yield of wheat due to hormonal induced amelioration under salinity could be associated with increase photosynthesis (Jayakannan et al., 2015; Agami et al., 2013) carbohydrate accumulation (Khodary, 2004) and strengthening the defense system of wheat (Esan et al., 2017; Jini and Joseph, 2017). Many researchers have been explained that application of SA and L-TRP exhibited the halophytic properties in tomato (Molina et al., 2002), wheat (Senaratna et al., 2000) and cucumber (Shim et al., 2003) under exposure to salinity and osmotic stress. Results of present study revealed that application of hormones act as ant stressor and contents of $\mathrm{Na}^{+}$were decreased while that of $\mathrm{K}^{+}$was significantly increased. Similar results were reported in Ocimum Basilicucm (Parizi et al., 2011), Arabidopsis (Jayakannan et al., 2013) and in broad bean (Azooz et al., 2011).

Soil properties: Post-harvest soil analysis revealed that gypsum application substantially improved the soil chemicals and physical properties than without gypsum and effect was more pronounced where hormones were also used. Chemical properties like $\mathrm{EC}_{\mathrm{e}}, \mathrm{pH}_{\mathrm{s}}$, and $\mathrm{SAR}$ were substantially decreased with gypsum application at the end of study. The decrease in these salinity indicators is implicitly attained to the fact that gypsum released $\mathrm{Ca}^{2+}$ which replaced $\mathrm{Na}^{+}$from exchange site leading to decline in $\mathrm{pH}_{\mathrm{s}}, \mathrm{EC}_{\mathrm{e}}$ and SAR (Qadir and Oster, 2002; Ghafoor et al., 2008). Improvement in soil physical properties (bulk density and hydraulic conductivity) may be attributed to leaching of salts from root zone (Richards, 1954; Oster, 1982). The beneficial effect of gypsum in lowering soil $\mathrm{EC}_{\mathrm{e}}, \mathrm{SAR}$, alkaline $\mathrm{pH}_{\mathrm{s}}$ values, bulk density, improved infiltration rate, hydraulic conductivity and porosity have been reported in many studies (Ahmed et al., 2015; Murtaza et al., 2017). 
Conclusion: It is well documented that hormones act as anti-stressor in response to environmental conditions, but their use in agriculture is not yet well developed. Combined use of gypsum and stress modifiers hormones could be highly interesting from a practical point of view, offering novel tools or approaches for plant stress management. Although hormones are not a remedy, but in present study these effectively improved agronomical and yield characteristics of wheat and mitigated the adverse effects of salt stress. Thus, from the results of current study, it can be suggested that tested hormones SA and L-tryptophan act cooperatively and in future, combination of these hormones with gypsum can be used positively to increase commercial benefit of wheat crop in salt affected soil conditions.

\section{REFRENCES}

Agami, R.A. (2013). Alleviating the adverse effects of $\mathrm{NaCl}$ stress in maize seedlings by pretreating seeds with salicylic acid and 24-epibrassinolide. South Afri. J. Botany. 88: 171-177.

Ahmed, K., G. Qadir, A.R. Jami, M.Q. Nawaz, A. Rehim, K. Jabran and M. Hussain. (2015). Gypsum and farm manure application with chiseling improve soil properties and performance of fodder beet under saline-sodic conditions. Int. J. Agric. Biol. 17: 1225-1230.

Amjad, M., J. Akhtar, M.A. Haq, M.A. Riaz and S.E. Jacobsen. (2014). Understanding salt tolerance mechanisms in wheat genotypes by exploring antioxidant enzymes. Pakistan J. Agri. Sci. 51(4): 969-976.

Anaya, F., R. Fghire, S. Wahbi and K. Loutfi. (2015). Influence of salicylic acid on seed germination of Vicia faba L. under salt stress. J. Saudi Society of Agri. Sci. 1-8.

Asada, K. (2006). Production and scavenging of reactive oxygen species in chloroplasts and their functions. Plant Physiol. 141: 391-396.

Azooz, M. M., A.M. Youssef and P. Ahmad. (2011). Evaluation of salicylic acid (SA) application on growth, osmotic solutes and antioxidant enzyme activities on broad bean seedlings grown under diluted seawater. Int. J. Plant Physiol. Biochem. 3: 253-264.

Babar, S., E. H. Siddiqi, I. Hussain, K.H. Bhatti and R. Rasheed. (2014). Mitigating the effects of salinity by foliar application of salicylic acid in fenugreek. Physiology J. 2014, Article ID 869058. 1-6.

Cosgrove, D.J., S. Gilroy, T. Kao, H. Ma and J.C. Schultz. (2000). Plant signaling cross talk among geneticists, physiologists, and ecologists. Plant Physiol. 124: 499-506.
Daneshmand, F., M.J. Arvin and K.M. Kalantari. (2010), Physiological responses to $\mathrm{NaCl}$ stress in three wild species of potato in vitro. Acta Physiol. Plant. 32: 91-101.

Desoky, E.M. and A.R.M. Merwad. (2015). Improving the salinity tolerance in wheat plants using salicylic and ascorbic acids. J. Agric. Sci. 7: 203-217.

El-Tayeb, M. (2005). Response of barley grains to the interactive effect of salinity and salicylic acid. Plant Growth Regulation. 45: 215-224.

Esan, A.M., K. Masisib, F.A. Dadac and C.O. Olaiya. (2017). Comparative effects of indole acetic acid and salicylic acid on oxidative stress marker and antioxidant potential of okra (Abelmoschus esculentus) fruit under salinity stress. Sci. Horti. 216: 278-283.

Ghafoor, A., G. Murtaza, B. Ahmad and T.M. Boers. (2008). Evaluation of amelioration treatments and economic aspects of using saline-sodic water for rice and wheat production on saltaffected soils under arid land conditions. Irri. Drain. 57: 424-434.

Hala M.S. (2005). Physiological responses of wheat to salinity alleviation by Nicotinamide and Tryptophan. Int. J. Agric. Biol. 7: 653-659.

Hameed, A., N. Bibi, J. Akhter and N. Iqbal. (2011). Differential changes in antioxidants, proteases, and lipid peroxidation in flag leaves of wheat genotypes under different levels of water deficit conditions. Plant Physiol. Biochem. 49: 178185.

Herrera-Vasquez, A., P. Salinas and L. Holuigue. (2015). Salicylic acid and reactive oxygen species interplay in the transcriptional control of defense genes expression. Front. Plant Sci. 6: 171-176.

Horvath, E., J. Csiszar, A. Galle, P. Poor, A. Szepesi and I. Tari. (2015). Hardening with salicylic acid induces concentration-dependent changes in abscisic acid biosynthesis of tomato under salt stress. J. Plant Physiol. 183: 54-63.

Hussain, M.M., S.Y. Faham and A.K. Alva. (2014). Role of foliar application of nicotinic acid and tryptophan on onion plants response to salinity stress. J. Agric. Sci. 6: 41-51.

Iqbal, M. and M. Ashraf. (2013). Salt tolerance and regulation of gas exchange and hormonal homeostasis by auxin-priming in wheat. Brasilia. 48: 1210-1219.

Jayakannan, M., J. Bose, O. Babourina, Z. Rengel and S. Shabala. (2015). Salicylic acid in plant salinity stress signaling and tolerance. Plant Growth Regul. 76: 25-40.

Jayakannan, M., J. Bose, O. Babourina, Z. Rengel and S. Shabala. (2013). Salicylic acid improves salinity 
tolerance in Arabidopsis by restoring membrane potential and preventing salt-induced $\mathrm{K}^{+}$loss via a GORK channel. J. Exp. Bot. 64: 2255-2268.

Jini, D. and B. Joseph. (2017). Physiological mechanism of salicylic acid for alleviation of salt stress in rice. Rice Science. 24: 97-108.

Kang, G., G. Li, G. Liu, W. Xu, X. Peng, C. Wang, Y. Zhu and T. Guo. (2013). Exogenous salicylic acid enhances wheat drought tolerance by influence on the expression of genes related to ascorbate-glutathione cycle. Biologia plantarum. 57: 718-724.

Khan, M.I.R., M. Fatma, T.S. Per, N.A. Anjum and N.A. Khan. (2015). Salicylic acid-induced abiotic stress tolerance and underlying mechanisms in plants. Front. Plant Sci. 6: 462.

Khodary, S.E.A. (2004). Effect of salicylic acid on the growth, photosynthesis and carbohydrate metabolism in salt-stressed maize plants. Int. J. Agric. Biol. 6: 5-8.

Kumar, J., V.P. Singh and S.M. Prasad. (2015). NaClinduced physiological and biochemical changes in two cyanobacteria Nostoc muscorum and Phormidium foveolarum acclimatized to different photosynthetically active radiation. J. Photochem. Photobiol. B: Biol. 151: 221-232.

Merwad, A.M.A. and M.K. Abdel-Fattah. (2015). Effect of some soil amendments and foliar spray of salicylic and ascorbic acids on sorghum under saline calcareous soil conditions. Internal. J. Soil Sci. 10: 28-36.

Miao, Y., Z. Zhu, Q. Guo, H. Ma and L. Zhu. (2015). Alternate wetting and drying irrigation mediated changes in the growth, photosynthesis and yield of the medicinal plant Tulipa edulis. Ind. Crops Prod. 66: 81-88.

Miransari, M. and D.L. Smith. (2014). Plant hormones and seed germination. Environ. Exp. Bot. 99: 110-21.

Mittler, R. (2002). Oxidative stress, antioxidants and stress tolerance. Trends in plant sci. 7: 405- 410.

Mohite, B. (2013). Isolation and characterization of indole acetic acid (IAA) producing bacteria from rhizospheric soil and its effect on plant growth. J. Soil Sci. Plant Nutr. 13: 638-649.

Molina, A., P. Bueno, M.C. Marın, M.P. RodriguezRosales, A. Belver, K. Venema and J.P. Donaire. (2002). Involvement of endogenous salicylic acid content, lipoxygenase and antioxidant enzyme activities in the response of tomato cell suspension cultures to $\mathrm{NaCl}$. New Phytol. 156: 409-415.

Munns, R., R.A. James and A. Lauchli. (2006). Approaches to increasing the salt tolerance of wheat and other cereals. J. Exp. Botany. 57:1025-1043.
Murtaza, B., G. Murtaza, M. Sabir, G. Owens, G. Abbas, M. Imran and G.M. Shah. (2017). Amelioration of saline-sodic soil with gypsum can increase yield and nitrogen use efficiency in rice-wheat cropping system. Archives of Agronomy and Soil Sci. 63: 1267-1280.

Oster, J.D. (1982). Gypsum usage in irrigated agriculture: a review. Fert. Res. 3: 73-89.

Parizi, M.D., K.M. Kalantari, S. Enteshari and A. Baghizadeh. (2011). Effect of salicylic acid and salt stress on $\mathrm{Na}$ and $\mathrm{K}$ content in Ocimum basilicum L. Iran J. Plant. Physiol.,1: 135-139.

Qadir, M. and J.D. Oster. (2002). Crop and irrigation management strategies for saline-sodic soils and waters aimed at environmentally sustainable agriculture. Sci. Total Environ., 323:1-19.

Rai. V.K. (2002). Role of amino acid in plant responses to stresses. Biol. Plantarum J. 45: 481-487.

Rao, S.R., A. Qayyum, A. Razzaq, M. Ahmad, I. Mahmood and A. Sher. (2012). Role of foliar application of salicylic acid and L-tryptophan in drought tolerance of maize. J. Animal \& Plant Sci. 22: 768-772.

Riaz, M.A., M. Saqib, J. Akhtar and R. Ahmad. (2012). Interactive effect of salinity and boron application on growth and physiological traits of sunflower (Helianthus annuus L.) genotypes. Soil and Environment. 31(2):119-124.

Riaz, M.A., M. Saqib, J. Akhtar, S. Pervaiz and M.A. Haq. (2008). Evaluation of sunflower (Helianthus annuus L.) genotypes in relation to biomass and ionic production concentration under salt stress. Soil and Environment. 27: 99105.

Richards, L.A. (1954). Diagnosis and improvement of saline and alkali soils. Agriculture. Handbook No. 60. United States Department of Agriculture. Govt. Printing Office, Washington, D.C

Said-Al Ahl, H., A. El-Gendy and E. Omer. (2014). Effect of ascorbic acid, salicylic acid on coriander productivity and essential oil cultivated in two different locations. Adv. Environ., Biol. 8: 2236-2250.

Saqib, Z.A., J. Akhtar, M.A. Ul-Haq and I. Ahmad. (2012). Salt induced changes in leaf phenology of wheat plants are regulated by accumulation and distribution pattern of $\mathrm{Na}^{+}$ion. Pakistan $\mathrm{J}$. Agric. Sci. 49: 141-148.

Senaratna, D. Touchell, T. Bunn and K. Dixon. (2000). Acetyl salicylic acid (Aspirin) and salicylic acid induce multiple stress tolerance in bean and tomato plants. Plant Growth Regul. 30: 157-161.

Shim, I.S., Y. Momose, A. Yamamoto, D.W. Kim and K. Usui. (2003). Inhibition of catalase activity by oxidative stress and its relationship to salicylic 
acid accumulation in plants. Plant Growth Regul. 39: 285-292.

Steel, R.G.D., J.H. Torrie and D.A. Dickey (1997). Principles and Procedures of Statistic: A Biometrical Approach. 3rd edition, pp: 400-428. Mc Graw Hill book Co. Inc. New York, USA.

Sudhir, P. and S.D.S. Murthy. (2004). Effects of salt stress on basic processes of photosynthesis. Photosynthetica. 42: 481-486.

Szabolcs, I. (1994). Soils and salinization. In: Hand-book of Plant and Crop Stress, pp: 3-11. Pessarakli, M. (ed.). Marcel Dekker, New York.

Tamas, L., I. Mistrik, A. Alemayehu, V. Zelinova, B. Bocova and J. Huttova. (2015). Salicylic acid alleviates cadmium-induced stress responses through the inhibition of $\mathrm{Cd}$-induced auxinmediated reactive oxygen species production in barley root tips. J. Plant Physiol. 173: 1-8.

Tiwari, J.K., A.D. Munshi, R. Kumar, R.N. Pandey, A. Arora, J.S. Bhat and A.K. Sureja. (2010). Effect of salt stress on cucumber: $\mathrm{Na}^{+} / \mathrm{K}^{+}$ratio, osmolyte concentration, phenols and chlorophyll content. Acta Physiol. Plant. 32: 103-114.

Tufail, A., M. Arfan, A.R. Gurmani, A. Khan and A. Bano. (2013). Salicylic acid induced salinity tolerance in maize (zea mays). Pakistan J. Bot. 45: $75-82$.

U.S. Salinity Lab. Staff. (1969). Diagnosis and Improvement of Saline and Alkali Soils. USDA Handbook 60, Washington DC, USA.
Vaishnav, A., S. Kumari, S. Jain, A. Varma and D.K. Choudhary. (2015). Putative bacterial volatilemediated growth in soybean (Glycine $\max \mathrm{L}$. Merrill) and expression of induced proteins under salt stress. J. Appl. Microbiol. 119: 539551.

Verma, V., P. Ravindran and P.P. Kumar (2016). Plant hormone-mediated regulation of stress responses. BMC Plant Biol. 86: 14-16.

Visentin, I., M. Vitali, M. Ferrero, Y. Zhang, C. RuyterSpira, O. Novak, M. Strnad, C. Lovisolo, A. Schubert and F. Cardinale. (2016). Low levels of strigolactones in roots as a component of the systemic signal of drought stress in tomato. New Phytol. 212: 954-963.

Wani, S.H., V. Kumar, V. Shriram and S.K. Sah (2016). Phytohormones and their metabolic engineering for abiotic stress tolerance in crop plants. The Crop J. 4: 162-176.

Xiong, L., K.S. Schumaker and J.K. Zhu. (2002). Cell signaling during cold, drought, and salt stress. The Plant Cell. 14: 165-183.

Zahir, A.Z., M.A. Malik and M. Arshad. (2000). Improving crop yields by the application of an auxin precursor L-tryptophan. J. Biol. Sci. 3: 133-135. 